\title{
Triterpenes and Sterols from Leaves of Hoya meliflua Merr.
}

\author{
Vincent Antonio S. Ng ${ }^{1,}$, Raymond S. Malabed ${ }^{2}$, Fernando B. Aurigue ${ }^{3}$, Consolacion Y. Ragasa ${ }^{1,4}$
}

\section{Vincent Antonio S. $\mathrm{Ng}^{1, *}$, Raymond S. Malabed", Fernando B. Aurigue ${ }^{3}$, Consolacion Y. Ragasa ${ }^{1,4}$}

'Chemistry Department, De La Salle University, 2401 Taft Avenue, Manila 1004, PHILIPPINES.

2Department of Chemistry, Graduate School of Science, Osaka University, Osaka 560-0043, JAPAN.

${ }^{3}$ Agriculture Research Section, Atomic Research Division, Philippine Nuclear Research Institute-Department of Science and Technology, Commonwealth Avenue, Diliman, Quezon City 1101, PHILIPPINES.

${ }^{4}$ Chemistry Department, De La Salle University Science and Technology Complex Leandro V. Locsin Campus, Biñan City, Laguna 4024, PHILIPPINES.

\section{Correspondence}

Dr. Vincent Antonio S. Ng

Chemistry Department, De La Salle University, 2401 Taft Avenue, Manila 1004, PHILIPPINES

Phone no : +632-5360230

E-mail: vincent.ng@dlsu.edu.ph

History

- Submission Date: 25-07-2018;

- Review completed: 04-10-2018.

- Accepted Date: 01-11-2018

\section{DOI : 10.5530/pj.2019.1.9}

Article Available online

http://www.phcogj.com/v11/i1

Copyright

(C) 2019 Phcog.Net. This is an openaccess article distributed under the terms of the Creative Commons Attribution 4.0 International license.

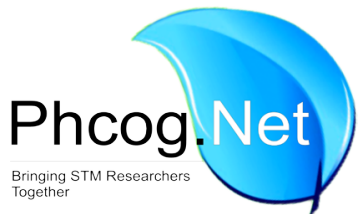

\begin{abstract}
Introduction: Hoya plants are also called wax plants due to the waxy appearance of their leaves and flowers. Most species are cultivated as ornamental plants. In the Philippines, there are at least 109 species of Hoya; 88 of these are endemic to the country. One of the endemic species is Hoya meliflua often confused with $\mathrm{H}$. diversifolia, which can also be found in other countries. This study is part of our research on the chemical constituents of Philippine native Hoyas. Methods: The compounds were isolated by silica gel chromatography and identified by NMR spectroscopy. Results: Chemical investigation of the dichloromethane extract from the leaves of Hoya meliflua afforded squalene and mixtures of $\beta$-amyrin (1a), $\alpha$-amyrin (1) and lupeol (1c) in about 1:1:0.25 ratio; oleanone (2a), ursenone (2b) and lupenone (2c) in about $1: 1: 0.3$ ratio; $\beta$-amyrin cinnamate $(\mathbf{3 a}), \alpha$-amyrin cinnamate $(\mathbf{3} \mathbf{b})$ and lupenyl cinnamate $(\mathbf{3} \mathbf{c})$ in about 0.5:0.3:1 ratio; and $\beta$-sitosterol and stigmasterol in about 5:1 ratio. Conclusion: The results of our study indicate that Hoya meliflua shares similar chemical characteristics with other members of the genus Hoya. The triterpenes and sterols obtained from $\mathrm{H}$. meliflua were also identified from other Hoya species. It is interesting to note that although most Hoya plants have no known biological activity and medicinal property, the compounds isolated from H. meliflua possess diverse bioactivities.

Key words: Hoya meliflua, Apocynaceae, Squalene, $\beta$-amyrin, $\alpha$-amyrin, Lupeol, Oleanone, Ursenone, Lupenone, $\beta$-amyrin Cinnamate, $\alpha$-amyrin Cinnamate, Lupenyl Cinnamate, $\beta$-sitosterol, Stigmasterol.
\end{abstract}

\section{INTRODUCTION}

Hoya $\mathrm{Br}$. is considered the largest genus of flowering plants in the family Apocynaceae. Commonly called wax plants due to the waxy appearance of their leaves and flowers, most species have ornamental value. A few have been reported to have medicinal properties or used in traditional medicine. In the Philippines, there are at least 109 species of Hoya; 88 of these are endemic to the country. One such endemic species is Hoya meliflua Merr. found in Apayao, Bataan, Laguna, La Union and Rizal in Luzon Island and in Leyte, Mindoro, Negros, Palawan and Panay islands in Central Philippines all at low altitudes. ${ }^{1}$ New records of occurrence in other provinces, such as Laguna, have not been published yet. The Plant List. ${ }^{2}$ states that H. meliflua is an unresolved name because some data suggest that it is synonymous with $H$. diversifolia Blume which is also found in other countries. This may be attributed to the confusion on the identity of the two Philippine native species.

This study is part of our research on the chemical constituents of Philippine native hoyas. We earlier reported the isolation of lupenone (I) and lupeol (II) from the roots; II, squalene (III) and $\beta$-sitosterol (IV) from the leaves; and betulin (V) from the stems of $H$. mindorensis Schlechter. ${ }^{3}$ In another study, we reported the isolation of II, $\alpha$-amyrin (VI), $\beta$-amyrin (VII), lupeol acetate (VIII), $\alpha$-amyrin acetate (IX) and $\beta$-amyrin acetate $(\mathbf{X})$ from the stems; and III, IV, VI, bauerenol (XI), lutein (XII) and stigmasterol (XIII) from the leaves of $H$. multiflora Blume. ${ }^{4}$ Furthermore, the isolation of $\beta$-amyrin cinnamate (XIV) and taraxerol (XV) from the stems; and IV, XIII, XV, triglycerides (XVI) and chlorophyll a (XVII) from the leaves of $H$. wayetii Kloppenb has been reported. ${ }^{5}$ Moreover, the isolation of IV, XIII, $\mathbf{X I V}, \mathbf{X V}$, taraxerone (XVIII) and $\alpha$-amyrin cinnamate (XIX) from the stems; IV, XV and XVIII from the roots; XIV and XIX from the flowers; and III, IV and saturated hydrocarbons (XX) from the leaves of $H$. buotii has been reported.

We also reported the isolation of II, III, IV, VI, VII, $\mathbf{X I V}$ and $\mathbf{X X}$ from the leaves; and III, IV, XIII, XV and lupeol cinnamate (XXI) from the stems of $H$. diversifolia Blume. ${ }^{7}$ Chemical investigation of the dichloromethane extracts of $H$. cumingiana Decne. yielded II, IV, VI, VII, XIII and bauerenol (XXII) from the leaves; and XV from the stems. ${ }^{8}$ Recently, we reported the isolation of IV, XIII and XV from the stems ${ }^{9}$ and I, IV, XIII, 2-hydroxyethylbenzoate (XXIII) and fatty acid methyl esters (XXIV) from the leaves ${ }^{10}$ of Hoya pubicalyx. In another study, the dichloromethane extracts of $H$. paziae Kloppenb. yielded IX, X, XV and taraxeryl acetate (XXV) from the stems ${ }^{11}$ and II, VI, VII, lupeol fatty acid esters 
(XXVI), $\alpha$-amyrin fatty acid esters (XXVII) and $\beta$-amyrin fatty acid esters (XXVIII) from the leaves. ${ }^{12}$ Furthermore, the dichloromethane extracts of $H$. cagayanensis afforded I, II, IV, XIII, XX and dihydrocanaric acid (XXIX), from the stems; and 2-hydroxyethyl benzoate (XXX) from the leaves. ${ }^{13}$ Recently, the dichloromethane extracts of $H$. madulidii yielded II, IV, XIII, XIV, XIX, XX and XXI from the stems and III, IV, XIII, XVII and XX from the leaves. ${ }^{14}$

In this study, the dichloromethane extract of the leaves of Hoya meliflua yielded squalene, $\beta$-amyrin (1a), $\alpha$-amyrin (1b), lupeol (1c), oleanone (2a), ursenone (2b), lupenone (2c), $\beta$-amyrin cinnamate (3a), $a$-amyrin cinnamate (3b), lupenyl cinnamate $(\mathbf{3} \mathbf{c}), \beta$-sitosterol and stigmasterol (Figure 1).

\section{MATERIALS AND METHODS}

\section{General Experimental Procedure}

Sample spectra were obtained on a JEOL ECS 400 spectrometer with $\mathrm{CDCl}_{3}$ as solvent. Column chromatography was performed, with silica gel 60 (70-230 mesh). Thin layer chromatography was performed with plastic backed plates coated with silica gel $\mathrm{F}_{254}$ and the plates were visualized by spraying with vanillin/ $\mathrm{H}_{2} \mathrm{SO}_{4}$ solution followed by warming.

\section{Sample Collection}

Hoya meliflua leaves and stems were collected from healthy vines of a clone that has been cultivated for more than 10 years. Samples labeled as PNRI-H.CA were provided under Material Transfer Agreement No. 2016-004 dated June 24, 2016. The original plant came from Quezon Province, Philippines and authenticated by one of the authors (FBA).

\section{General Isolation Procedure}

A glass column 12 inches in height with 0.5 inch internal diameter was used for the fractionation of the crude extract. Fractions of $10 \mathrm{~mL}$ volumes were collected and monitored by thin layer chromatography. Fractions containing spots with similar $R f$ values were combined and rechromatographed using the appropriate solvent. Final purification was carried out using Pasteur pipette as the column, collecting $1 \mathrm{~mL}$ fractions. TLC-pure isolates were combined and after evaporation of the solvent, were subjected to NMR analysis.

\section{Isolation of Chemical Constituents of the Leaves}

The air-dried leaves (252.8 g) were ground in a blender, soaked in $\mathrm{CH}_{2} \mathrm{Cl}_{2}$ for three days and then filtered. The filtrate was concentrated under vacuum to afford a crude extract ( $7.8 \mathrm{~g}$ ) which was chromatographed by gradient elution with $\mathrm{CH}_{2} \mathrm{Cl}_{2}$, followed by increasing amounts of acetone at $10 \%$ increment by volume as eluents.

The $\mathrm{CH}_{2} \mathrm{Cl}_{2}$ fraction was rechromatographed $(2 \times)$ using petroleum ether to afford squalene $(12.8 \mathrm{mg})$. The $10 \%$ acetone in $\mathrm{CH}_{2} \mathrm{Cl}_{2}$ fraction was rechromatographed $(3 \times)$ using $1 \%$ EtOAc in petroleum ether to yield a mixture of $\mathbf{3 a}, \mathbf{3 b}$ and $\mathbf{3} \mathbf{c}(5.0 \mathrm{mg})$, after washing with petroleum ether. The $20 \%$ acetone in $\mathrm{CH}_{2} \mathrm{Cl}_{2}$ fraction was rechromatographed $(3 \times)$ using $2.5 \%$ EtOAc in petroleum ether to yield a mixture of $\mathbf{2 a}, \mathbf{2} \mathbf{b}$ and $2 \mathrm{c}(10.3 \mathrm{mg})$, after washing with petroleum ether. The $30 \%$ acetone in $\mathrm{CH}_{2} \mathrm{Cl}_{2}$ fraction was rechromatographed $(4 \times)$ using $7.5 \% \mathrm{EtOAc}$ in petroleum ether to afford a mixture of $\mathbf{1 a}, \mathbf{1 b}$ and $\mathbf{1 c}(10.6 \mathrm{mg})$ after washing with petroleum ether. The $40 \%$ acetone in $\mathrm{CH}_{2} \mathrm{Cl}_{2}$ fractions was rechromatographed $(3 \times)$ using $10 \%$ EtOAc in petroleum ether to yield a mixture of $\beta$-sitosterol and stigmasterol $(21.0 \mathrm{mg})$ after washing with petroleum ether.

\section{RESULTS AND DISCUSSION}

Silica gel chromatography of the dichloromethane extract from the leaves of Hoya meliflua afforded squalene and mixtures of $\beta$-amyrin (1a), a-amyrin (1b) and lupeol (1c) in about 1:1:0.25 ratio; oleanone (2a), ursenone (2b) and lupenone (2c) in about 1:1:0.3 ratio; $\beta$-amyrin cinnamate (3a), $\alpha$-amyrin cinnamate (3b) and lupenyl cinnamate $(\mathbf{3 c})$ in about 0.5:0.3:1 ratio; and $\beta$-sitosterol and stigmasterol in about 5:1 ratio. The structures of these compounds were identified by comparison of their NMR data with those reported in the literature.

The NMR spectra of $\mathbf{1 a}$ are in accordance with data reported in the literature for $\beta$-amyrin, ${ }^{4} \mathbf{1 b}$ for $\alpha$-amyrin, ${ }^{4} \mathbf{1} \mathbf{c}$ for lupeol, ${ }^{4} \mathbf{2} \mathbf{a}$ for oleanone, ${ }^{15}$ 2b for ursenone, ${ }^{15} \mathbf{2 c}$ for lupenone, ${ }^{16}$ 3a for $\beta$-amyrin cinnamate, ${ }^{6,17}$ 3b for $\alpha$-amyrin cinnamate, ${ }^{6,17} 3$ c for lupeol cinnamate, ${ }^{17}$ squalene, ${ }^{18}$ $\beta$-sitosterol ${ }^{18}$ and stigmasterol. ${ }^{18}$

The ratio of about 1:1:0.25 for the mixture of $\beta$-amyrin (1a), $\alpha$-amyrin (1b) and lupeol (1c) was deduced from the intensities and integrations of the ${ }^{1} \mathrm{H}$ NMR resonances for the olefinic protons of $1 \mathrm{a}$ at $\delta 5.16$ (brs), ${ }^{7,12}$ $\mathbf{1 b}$ at $\delta 5.11$ (brs) $)^{7,12}$ and $\mathbf{1 c}$ at $\delta 4.68$ (brs) and 4.56 (brs)., ${ }^{7,18}$ The ratio of about 1:1:0.30 for the mixture of oleanone (2a), ursenone (2b) and lupenone (2c) was deduced from the intensities and integrations of the ${ }^{1} \mathrm{H}$ NMR resonances for the olefinic protons of $2 \mathrm{a}$ at $\delta 5.19(\mathrm{t}, J=3.2$ $\mathrm{Hz}),{ }^{15} \mathbf{2 b}$ at $\delta 5.14(\mathrm{t}, J=3.2 \mathrm{~Hz})^{15}$ and $2 \mathrm{c}$ at $\delta 4.67$ (brs) and 4.55 (brs). ${ }^{19}$ The ratio of about $0.5: 0.3: 1$ for the mixture of $\beta$-amyrin cinnamate ( $3 a$ ), $\alpha$-amyrin cinnamate (3b) and lupenyl cinnamate (3c) was deduced from the intensities and integrations of the ${ }^{1} \mathrm{H}$ NMR resonances for the olefinic protons of $\mathbf{3 a} \delta 5.18$ (brs), ${ }^{6,17} \mathbf{3 b}$ at $\delta 5.13$ (brs); ${ }^{6,17}$ and $3 \mathbf{c}$ at $\delta$ 4.68 (br s) and 4.56 (br s). ${ }^{16}$ The ratio of about 5:1 for the mixture of $\beta$-sitosterol and stigmasterol was deduced from the intensities and integrations of the ${ }^{1} \mathrm{H}$ NMR resonances for olefinic protons at $\delta 5.33$ (brs, H-5) and methyl protons at $\delta 0.66$ (s) for $\beta$-sitoterol and olefinic protons at $\delta 5.33$ (brs, H-5), $5.13(\mathrm{dd}, \mathrm{J}=8.4,15.2 \mathrm{~Hz})$ and 5.00 $(\mathrm{dd}, \mathrm{J}=8.4,15.2 \mathrm{~Hz})$ and the methyl protons at $\delta 0.68(\mathrm{~s})$ for stigmasterol. ${ }^{18}$

H. meliflua is cultivated as an ornamental plant in the Philippines. There is no reported biological activity and medicinal property for the plant, but Blanco ${ }^{20}$ mentioned as early as 1845 a record that $H$. meliflua causes "stoppage of birth," or perhaps as an abortifacient. However, literature search revealed that the compounds isolated from the plant possess diverse activities.

$\beta$-Amyrin (1a) and $\alpha$-amyrin (1b) were reported to possess anti-inflammatory. ${ }^{21-23}$ and analgesic ${ }^{24-25}$ properties

Triterpene 1a showed antifungal activity against $A$. rabiei with an MIC value of $0.0156 \mathrm{mg} / \mathrm{mL},{ }^{26}$ while $\mathbf{1} \mathbf{b}$ was proposed as a possible biomarker for the fungal resistance of grape-vine leaves (Vitis vinifera). ${ }^{27}$ The mixture of $\mathbf{1 a}$ and $\mathbf{1 b}$ effectively reduced the elevated plasma glucose levels during the oral glucose tolerance test (OGTT). Furthermore, the mixture of $\mathbf{1 a}$ and $\mathbf{1 b}$ at $100 \mathrm{mg} / \mathrm{kg}$ significantly decreased the VLDL and LDL cholesterol and increased the HDL cholesterol. ${ }^{28} \mathrm{~A}$ review on the sources and biological activities of $\mathbf{1 a}$ and $\mathbf{1} \mathbf{b}$ has been provided. ${ }^{29}$

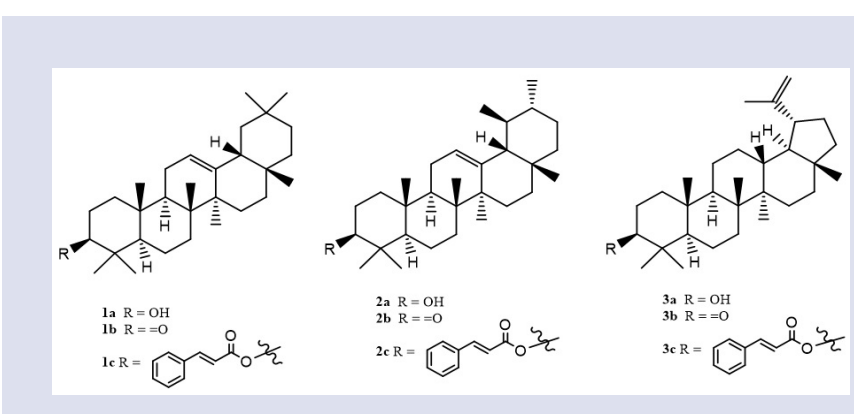

Figure 1: Chemical structures of $\beta$-amyrin (1a), $a$-amyrin (1b), lupeol $(1 c)$, oleanone $(2 a)$, ursenone $(2 b)$, lupenone $(2 c), \beta$-amyrin cinnamate (3a), a-amyrin cinnamate (3b) and lupenyl cinnamate (3c). 
On the other hand, lupeol (1c) exhibited antiurolithiatic and diuretic activity. ${ }^{30}$ It prevented the formation of vesical calculi and reduced the size of the preformed stones in rats. ${ }^{31}$ It also showed antifungal activity against Fusarium oxysporum and Penicillium notatum. ${ }^{32}$ Triterpene 1c significantly reduced the 451Lu tumor growth in athymic nude mice, ${ }^{33}$ inhibited the proliferation of MDA-MB-231 human breast cancer cells in a dose dependent manner ${ }^{34}$ and induced growth inhibition and apoptosis in hepatocellular carcinoma SMMC7721 cells by down- regulation of the death receptor 3 (DR3) expression. ${ }^{35}$ It exhibited potent anti-inflammatory activity in an allergic airway inflammation model by a significant reduction in eosinophils infiltration and in Th2-associated cytokines levels that trigger the immune responses in asthma. ${ }^{36}$ Another study reported that 1c and lupeol acetate have shown hypotensive activity. ${ }^{37}$ A review on the biological activities of lupeol has been provided. ${ }^{38}$

Lupenone (2c) inhibited adipocyte differentiation by suppressing PPAR $\gamma$ and $\mathrm{C} / \mathrm{EBP} \alpha$ protein levels. ${ }^{39}$ It also increased the tyrosinase enzyme expression via mitogen-activated protein kinase phosphorylated extracellular signal regulated kinases 1 and 2 phosphorylation inhibition which results to stimulation of melanogenesis. This suggests that $2 \mathrm{c}$ could be a possible treatment for hypopigmentation. ${ }^{40}$

$\beta$-Amyrin cinnamate (3a) was reported to inhibit the TPAS-induced inflammation ( $\operatorname{ID}_{50} 0.27 \mu \mathrm{mol} / \mathrm{ear}$; CI $95 \% 0.23-0.33 \mu \mathrm{mol} / \mathrm{ear}$ ) which is more inhibitory than the positive control, indomethacin $\left(\mathrm{ID}_{50} 0.91 \mu \mathrm{mol} /\right.$ ear ;CI 95\% 0.23-0.33 $\mathrm{mmol} / \mathrm{ear}$ ). ${ }^{19}$ a-Amyrin cinnamate (3b), lupeol cinnamate $(\mathbf{3 c})$ and $\mathbf{3 a}$ exhibited marked anti-inflammatory activity against TPA-induced inflammation $\left(\mathrm{ID}_{50}=0.15-0.75 \mu \mathrm{mol} / \mathrm{ear}\right.$ ). Triterpene $3 c$ showed the highest activity with $\mathrm{ID}_{50}$ of $0.15 \mu \mathrm{mol} /$ ear. $^{12}$ This triterpene at a dose of $10 \mathrm{mg} / \mathrm{kg}$ also exhibited anti-inflammatory activity on rat hind paw edema induced by carrageenan. ${ }^{12}$ Furthermore, $3 c$ exhibited inhibitory effect on skin tumor promotion in an in vivo two-stage carcinogenesis test using DMBA as an initiator and TPA as a promoter. ${ }^{12}$ Triterpenes $\mathbf{3 a}-\mathbf{3} \mathbf{c}$ showed moderate inhibitory effects on Epstein-Barr virus early antigen (EBV-EA) in Raji cells as a primary screening test for inhibitors of tumor promoters. ${ }^{12}$

Squalene was reported to significantly suppress colonic ACF formation and crypt multiplicity which strengthened the hypothesis that it possesses chemopreventive activity against colon carcinogenesis. ${ }^{41}$ It showed cardioprotective effect which is related to inhibition of lipid accumulation by its hypolipidemic properties and/or its antioxidant properties. $^{42}$ A recent study reported that tocotrienols, carotenoids, squalene and coenzyme Q10 have anti-proliferative effects on breast cancer cells. ${ }^{43}$ The preventive and therapeutic potential of squalene containing compounds on tumor promotion and regression have been reported. ${ }^{44} \mathrm{~A}$ recent review on the bioactivities of squalene has been provided. ${ }^{45}$

$\beta$-Sitosterol was observed to have growth inhibitory effects on human breast MCF-7 and MDA- MB-231 adenocarcinoma cells. ${ }^{46}$ It was shown to be effective for the treatment of benign prostatic hyperplasia. ${ }^{47}$ It was also reported to attenuate $\beta$-catenin and PCNA expression, as well as quench radical in-vitro, making it a potential anticancer drug for colon carcinogenesis. ${ }^{48}$ It can inhibit the expression of NPC1L1 in the enterocytes to reduce intestinal cholesterol uptake. ${ }^{49}$ It was reported to induce apoptosis mediated by the activation of ERK and the downregulation of Akt in MCA-t102 murine fibrosarcoma cells. ${ }^{50}$

Stigmasterol showed therapeutic efficacy against Ehrlich ascites carcinoma bearing mice while conferring protection against cancer induced altered physiological conditions. ${ }^{51}$ It lowered plasma cholesterol levels, inhibited intestinal cholesterol and plant sterol absorption and suppressed hepatic cholesterol and classic bile acid synthesis in Winstar as well as WKY rats. ${ }^{52}$ Other studies reported that stigmasterol showed cytostatic activity against Hep-2 and McCoy cells, ${ }^{53}$ markedly inhibited tumour promotion in two stage carcinogenesis experiments, ${ }^{54}$ exhibited antimutagenic, ${ }^{55}$ topical anti-inflammatory, ${ }^{56}$ antiosteoarthritic ${ }^{57}$ and antioxidant ${ }^{58}$ activities.

\section{CONCLUSION}

The results of our study indicate that Hoya meliflua shares similar chemical characteristics with other members of the genus Hoya: $H$. multiflora, ${ }^{4}$ $H$. diversifolia, ${ }^{7} H$. cumingiana,${ }^{8}$ and $H$. paziae ${ }^{12}$ which yielded $\beta$-amyrin (1a) and $\alpha$-amyrin (1b); H. mindorensis, ${ }^{3} \mathrm{H}$. multiflora, ${ }^{4} \mathrm{H}$. diversifolia, ${ }^{7}$ H. cumingiana, ${ }^{8} \mathrm{H}$. paziae, ${ }^{12} \mathrm{H}$. cagayanensis, ${ }^{13}$ and $H$. madulidii ${ }^{14}$ which contained lupeol (1c); H. mindorensis, ${ }^{3} H$. pubicalyx, ${ }^{12}$ and $H$. cagayanensis ${ }^{15}$ which afforded lupenone (2c); H. wayetii, ${ }^{5} H$. buotii, ${ }^{6}$ and H. madulidii ${ }^{14}$ which yielded $\beta$-amyrin cinnamate (3a); H. buotii, ${ }^{6}$ and $H$. madulidii ${ }^{14}$ which afforded $\alpha$-amyrin cinnamate (3b); $H$. diversifolia ${ }^{7}$ and $H$. madulidii ${ }^{14}$ which provided lupenyl cinnamate (3c); H. mindorensis, ${ }^{3}$ H. multiflora ${ }^{4} H$. wayetii, ${ }^{5} H$. buotii ${ }^{6}{ }^{6}$. diversifolia,${ }^{7} H$. cumingiana, ${ }^{8}$ H. pubicalyx,${ }^{9,10} H$. cagayanensis, ${ }^{13}$ and $H$. madulidii ${ }^{14}$ which contained $\beta$-sitosterol and stigmasterol; and H. mindorensis, ${ }^{3} H$. buotii, ${ }^{6} H$. diversifolia $^{7}$ and $H$. madulidii ${ }^{14}$ which contained squalene. The most common constituents of the eleven native Hoya species studied are $\beta$-sitosterol and stigmasterol which are found in ten species. Of the twelve compounds isolated from $H$. meliflua, lupeol is found in eight species, squalene, $\beta$-amyrin and $\alpha$-amyrin in five species, lupenone and $\beta$-amyrin cinnamate in four species, $\alpha$-amyrin cinnamate and lupenyl cinnamate in three species. Oleanone and ursenone are reported for the first time from Philippine Hoya species.

It is interesting to note that although most Hoya plants have no known biological activity and medicinal property, the compounds isolated from H. meliflua possess diverse bioactivities.

Lastly, the difference in results of phytochemical analysis of $H$. meliflua is a proof that it is an entirely different and distinct species from H. diversifolia.

\section{ACKNOWLEDGEMENT}

VASN would like to thank Prof. Michio Murata of Osaka University for his generous assistance with the NMR measurements. A research grant from the University Research Coordinating Office (URCO) of De La Salle University Manila (07N1TAY16-2TAY17) is gratefully acknowledged.

\section{CONFLICT OF INTEREST}

The authors declare no conflict of interest.

\section{ABBREVIATIONS}

$\mathrm{CH}_{2} \mathrm{Cl}_{2}$ : Dichloromethane; EtOAc: Ethyl acetate; $\mathbf{E t}_{2} \mathrm{O}$ : Diethyl ether.

\section{REFERENCES}

1. Aurigue FB. A collection of Philippine hoyas and their culture. Los Baños, Laguna: PCAARRD-DSOST. 2013;195. (Book Series No.2/2013).

2. The Plant List. Version 1.1. Published on the Internet; http://www.the plantlist. org/ (accessed 13 ${ }^{\text {th }}$ July 2018). 2013.

3. Ebajo JVD, Shen CC, Ragasa CY. Triterpenes and sterol from Hoya mindorensis. Der Pharma Chemica. 2014;6(4):321-25.

4. Ebajo JVD, Shen CC, Ragasa CY. Terpenoids and sterols from Hoya multiflora Blume. J Appl Pharm Sci. 2015;5(3):33-9.

5. Ebajo JVD, Aurigue FB, Brkljaca R, Urban S, Ragasa CY. Chemical constituents of Hoya wayetii Kloppenb. Int J Pharmacog Phytochem Res. 2015;7(5):1041-5.

6. Ebajo JVD, Brkljaca R, Urban S, Ragasa CY. Chemical constituents of Hoya buotii Kloppenb. J Appl Pharm Sci. 2015;5(11):69-72.

7. Panajon NM, Aurigue FB, Shen CC, Ragasa CY. Triterpenes and sterols from Hoya diversifolia Blume. J Appl Pharm Sci. 2016;6(6):79-82.

8. Ragasa CY, Panajon NM, Aurigue FB, Brkljaca R, Urban S. Chemical constituents of Hoya cumingiana Decne. Int J Pharm Phytochem Res. 2016;8(12):2033-8.

9. Panajon NM, Aurigue FB, Shen CC, Ragasa CY. Triterpenes and sterols from 
Hoya pubicalyx Merr. Der Pharmacia Lettre. 2016;8(13):270-3.

10. Bolinget $E$, Panajon NM, Aurigue FB, Van AIA, Ragasa CY. Secondary metabolites from Hoya pubicalyx Merr. Res J Pharm Biol Chem Sci. 2017;7(2):678-81.

11. Borlagdan M, Aurigue $\mathrm{F}$, Van Al, Ragasa CY. Triterpenes from Hoya paziae Kloppenb. Phcog J. 2016;8(5):487-9.

12. Perez JDV, Borlagdan MS, Aurigue FB, Van AIA, Ragasa CY. Chemical constituents of Hoya paziae Kloppenb. Res J Pharm Biol Chem Sci. 2017;7(2):736-9.

13. Ragasa CY, Borlagdan MS, Aurigue FB, Brkljaca R, Urban S. Chemical constituents of Hoya cagayanensis CM Burton. J Appl Pharm Sci. 2017;7(5):61-5.

14. Borlagdan M, Aurigue FB, Shen CC, Ragasa CY. Chemical constituents of Hoya madulidii. Chem Nat Compd. 2018;54(4):198-9.

15. DeCarvalho MG, Velandia JR, DeOliveira LF, Bezerra FB. Triterpenos isolados de Eschweilera longipes Miers (Lecythidaceae). Qimica Nova. 1998;21(6):720-43.

16. Tsai PW, DeCastro-Cruz K, Shen CC, Ragasa CY. Chemical constituents of Broussonetia luzonicus. Phcog J. 2012;4(31):1-4.

17. Akihisa T, Kojima N, Kikuchi T, Yasukawa K, Tokuda H, Masters ET, et al. Antiinflammatory and chemopreventive effects of triterpene cinnamates and acetates from shea fat. J Oleo Sci. 2010;59(6):273-80.

18. Ragasa CY, Tan MCS, Fortin D, Shen CC. Chemical constituents of Ixora philippinensis. J Appl Pharm Sci. 2015;5(9):62-7.

19. Hisham A, Kumar GJ, Fujimoto Y, Hara N. Salacianone and salacianol, two triterpenes from Salacia beddomei. Phytochem. 1995;40(4):1227-31.

20. Blanco M. Flora de Filipinas: First English and modern Spanish edition. Intramuros, Manila: San Agustin Convent. 1993;3

21. Recio MC, Giner RM, Manez S, Rios JL. Structural requirements for the antiinflammatory activity of natural triterpenoids. Planta Med. 1995;61(2):181-5.

22. Madeiros R, Otuki MF, Avellar MC, Calixto J. Mechanisms underlying the inhibitory actions of the pentacyclic triterpene-amyrin in the mouse skin inflammation induced by phorbol ester 12-O-tetradecanoylphorbol-13-acetate. Eur J Pharmacol. 2007;55(9):227-35

23. Okoye NN, Ajaghaku DL, Okeke HN, llodigwe EE, Nworu CS, Okoye FBC. BetaAmyrin and alpha-amyrin acetate isolated from the stem bark of Alstonia boonei display profound anti inflammatory activity. Pharm Biol. 2014;52(11):1478-86.

24. Otuki C, Ferreira J, Lima F, Meyre-Silva C, Malheiros A, Muller L, et al. Antinociceptive properties of a mixture of $\alpha$-amyrin and $\beta$-amyrin triterpenes: evidence for participation of protein kinase $\mathrm{C}$ and protein kinase $\mathrm{A}$ pathways. J Pharmaco Exp Therapeutics. 2005;31(1):310-18.

25. Soldi C, Pizzolatti G, Luiz A, Marcon R, Meotti F, Miotob L, et al. Synthetic derivatives of the $\alpha$-and $\beta$-amyrin triterpenes and their antinociceptive properties. Bioorg Med Chem. 2008;16(6):3377-86.

26. Jabeen K, Javaid A, Ahmad E, Athar M. Antifungal compounds from Melia azederach leaves for management of Ascochyta rabiei, the cause of chick pea blight. Nat Prod Res. 2011;25(3):264-76.

27. Batovska DI, Todorova IT, Nedelcheva DV, Parushev SP, Atanassov AJ, Hvarleva TD, et al. Preliminary study on biomarkers for the fungal resistance in Vitis vinifera leaves. J Plant Physiol. 2008;165(8):791-5

28. Santos FA, Frota JT, Arruda BR, DeMelo TS, DeCarvalho AA, DaSilva A, et al. Antihyperglycemic and hypolipidemic effects of $\alpha, \beta$-amyrin, a triterpenoid mixture from Protium heptaphyllum in mice. Lipids in Health and Disease. 2012;11(1):98

29. Vázquez LH, Palazon J, Navarro-Ocaña A. The pentacyclic triterpenes, $\alpha$, $\beta$-amyrins: A review of sources and biological activities, Phytochemicals - A Global Perspective of Their Role in Nutrition and Health, Rao V (Ed.), ISBN: 978953-51-0296-0, In Tech, Available from: http://www.intechopen.com/books/phytochemicals-a-global-perspective-of-their-role-in-nutrition-and-health/the-pentacyclic-triterpenes-amyrins-a-review-of-sources-and-biological-activities. 2012.

30. Vidya L, Leni M, Varalakshmi P. Evaluation of the effect of triterpenes on urinary risk factors of stone formation in pyridoxine hyperoxaluric rats. Phytother Res. 2002;16(6):514-8.

31. Anand R, Patnaik GK, Kulshreshtha DK, Dhawan N. Antiurolithiatic activity of Iupeol, the active constituent of Crateva nuriala. Phytother Res. 1994;8(7):417-21.

32. Manzano PI, Miranda M, Abreu-Payrol J, Silva M, Sterner O, Peralta EL. Pentacyclic triterpenoids with antimicrobial activity from the leaves of Vernonanthura patens (Asteraceae). Emir J Food Agric. 2013;25(7):539-43.

33. Saleem M, Maddodi N, Zaid MA, Khan N, Hafeez B, Asim M, et al. Lupeol inhibits growth of highly aggressive human metastatic melanoma cells in vitro and in vivo by inducing apoptosis. Cancer Therapy: Preclinical. 2008;14(7):2119-27.

34. Lambertini E, Lampronti I, Penolazzi L, Khan MTH, Ather A, Giorgi G, et al. Expression of estrogen receptor gene in breast cancer cells treated with transcription factor decoy is modulated by Bangladeshi natural plant extracts. Oncol Res. 2005;15(2):69-79

35. Zhang $L$, Zhang $Y$, Zhang $L$, Yang $X$, Lv Z. Lupeol, a dietary triterpene, inhibited growth and induced apoptosis through downregulation of DR3 in SMMC7721 cells. Cancer Investigation. 2009;27(2):163-70.

36. Vasconcelos JF, Teixeira MM, Barbosa-Filho JM, Lúcio ASSC, Almeida JRGS, Queiroz LP, et al. The triterpenoid lupeol attenuates allergic airway inflammation in a murine model. Intl Immunopharmacol. 2008;8(9):1216-21.

37. Saleem R, Ahmad SI, Ahmed M, Faizi Z, Zikr-ur Rehman S, Ali M, et al. Hypotensive activity and toxicology of constituents from Bombax ceiba stem bark. Biol Pharm Bull. 2003;26(1):41-6

38. Gallo MBC, Sarachine MJ. Biological activities of lupeol. Intl J Biomed Pharm Sci. 2009;3(1):46-66.

39. Ahn EK, Oh JS. Lupenone isolated from Adenophora triphylla var. japonica extract inhibits adipogenic differentiation through the downregulation of PPAR $\gamma$ in 3T3-L1 cells. Phytother Res. 2013;27(5):761-6.

40. Villareal MO, Han J, Matsuyama M, Sekii $Y$, Smaoui A, Shigemori $H$, et al. Lupenone from Erica multiflora leaf extract stimulates melanogenesis in B16 murine melanoma cells through the inhibition of ERK1/2 activation. Planta Med. 2013:79(3-4):236-43

41. Rao CV, Mark HLN, Reddy BS. Chemo preventive effect of squalene on colon cancer. Carcinogenesis. 1998;19(2):287-90.

42. Farvin KHS, Anandan R, Hari S, Kumar S, Shing KS, Mathew S, et al . Cardio protective effect of squalene on lipid profile in isoprenaline induced myocardial infarction in rats. J Med Food. 2006;9(4):531-6.

43. Loganathan R, Selvaduray KR, Nesaretnam K, Radhakrisnan A. Differential and antagonistic effects of palm tocotrienols and other phytonutrients (carotenoids, squalene and coenzyme Q10) on breast cancer cells in vitro. J Oil Palm Res. 2013;25:208-15.

44. Desai KN, Wei H, Lamartiniere CA. The preventive and therapeutic potential of the squalene-containing compound, Roidex, on tumor promotion and regression. Cancer Lett. 1996;101(1):93-6.

45. Ronco AL, DeStéfani E. Squalene: a multi-task link in the crossroads of cancer and aging. Functional Foods in Health and Disease. 2013;3(12):462-76.

46. Awad AB, Chinnman M, Fink CS, Bradford PG. Sitosterol activates Fas signaling in human breast cancer cells. Phytomed. 2007;14(11):747-54

47. Jayaprakasha GK, Mandadi KK, Poulose SM, Jadegoud Y, Gowda GA, Patil BS Inhibition of colon cancer growth and antioxidant activity of bioactive compounds from Poncirus trifoliate (L.) Raf. Bioorg Med Chem. 2007;15(14):4923-32.

48. Baskar AA, Ignacimuthu S, Paulraj G, Numair K. Chemopreventive potential of $\beta$-sitosterol in experimental colon cancer model - an in vitro and in vivo study. BMC Comp Alt Med. 2010;10(1):24

49. Jesch ED, Seo JM, Carr TP, Lee JY. Sitosterol reduces messenger RNA and protein expression levels of Niemann-Pick C1-like1in FHs 74 Int cells. Nutr Res. 2009;29(12):859-66.

50. Moon DO, Kyeong-Jun L, Yung HC, Gi-Young K. Sitosterol-induced-apoptosis is mediated by the activation of ERK and the downregulation of Akt in MCA-102 murine fibrosarcoma cells. Int Immunopharmacol. 2007;7(8):1044-53.

51. Ghosh T, Maity TK, Singh J. Evaluation of antitumoractivity of stigmasterol, a constituent isolated from Bacopa monnieri Linn aerial parts against ehrlich ascites carcinoma in mice. Orient Pharm Exp Med. 2011;11(1):41-9.

52. Batta AK, Xu G, Honda A, Miyazaki T, Salen G. Stigmasterol reduces plasma cholesterol levels and inhibits hepatic synthesis and intestinal absorption in the rat. Metabolism. 2006;55(3):292-9.

53. Gómez MA, García MD, Sáenz MT. Cytostatic activity of Achillea ageratum L. Phytother Res. 2001;15(7):633-4.

54. Kasahara Y, Kumaki K, Katagiri S, Yasukawa K, Yamanouchi S, Takido M Carthami flos extract and its component, stigmasterol, inhibit tumour promotion in mouse skin two-stage carcinogenesis. Phytother Res. 1994;8(6):327-31.

55. Lim JC, Park JH, Budesinsky M, Kasal A, Han YH, Koo BS, et al. Antimutagenic constituents from the thorns of Gleditsia sinensis. Chem Pharm Bull. 2005;53(5):561-4

56. García MD, Sáenz MT, Gómez MA, Fernández MA. Topical anti-inflammatory activity of phytosterols isolated from Eryngium foetidum on chronic and acute inflammation models. Phytother Res. 1999;13(1):78-80.

57. Gabay O, Sanchez C, Salvat C, Chevy F, Breton M, Nourissat G. Stigmasterol: a phytosterol with potential anti-osteoarthritic properties. Osteoarthritis Cartilage. 2010;18(1):106-16

58. Panda S, Jafri M, Kar A, Meheta BK. Thyroid inhibitory, antiperoxidative and hypoglycemic effects of stigmasterol, isolated from Butea monosperma. Fitoter 2009;80(2):123-26. 
GRAPHICAL ABSTRACT

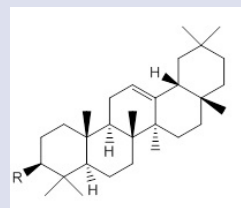

la $\mathrm{R}=\mathrm{OH}$
ib $\mathrm{R}=-\mathrm{O}$

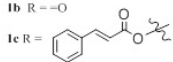

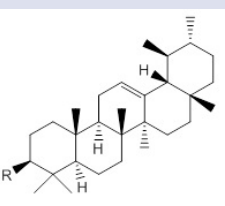

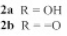

$2 \mathrm{er}-10$

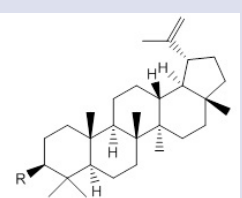

$3 \mathrm{a} \mathrm{R}=\mathrm{OH}$
$3 \mathrm{~b} \mathrm{R}=-\mathrm{O}$

$3 \mathrm{er}=1 \mathrm{~N} 0 \frac{2}{2}$

\section{SUMMARY}

- Chemical investigation of the dichloromethane extract from the leaves of Hoya meliflua afforded squalene and mixtures of $\beta$-amyrin (1a), $\alpha$-amyrin (1b) and lupeol (1c) in about 1:1:0.25 ratio; oleanone (2a), ursenone (2b) and lupenone $(2 \mathrm{c})$ in about $1: 1: 0.3$ ratio; $\beta$-amyrin cinnamate (3a), $\alpha$-amyrin cinnamate (3b) and lupenyl cinnamate $(3 c)$ in about 0.5:0.3:1 ratio; and $\beta$-sitosterol and stigmasterol in about 5:1 ratio. The structures of these compounds were identified by comparison of their NMR data with those reported in the literature.

Cite this article: Vincent AS. NG, Malabed RS, Aurigue FB, Ragasa CY. Triterpenes and Sterols from Leaves of Hoya meliflua Merr. Pharmacog J. 2019;11(1):48-52. 